\title{
Factors Associated to The Use of Iodized Salt by Housewives in Kecamatan Mila Kabupaten Pidie in 2020
}

\author{
${ }^{1}$ Ramadhaniah, ${ }^{2}$ Juwita, ${ }^{3}$ Fauzi Ali Amin, ${ }^{4}$ Afwa Hayuningtyas \\ ${ }^{1}$ University of Muhammadiyah Aceh, Indonesia, ramadhaniah@ gmail.com \\ ${ }^{2}$ University of Muhammadiyah Aceh, Indonesia, juwita@gmail.com \\ ${ }^{3}$ University of Muhammadiyah Aceh, Indonesia, fauzialiamin@gmail.com \\ ${ }^{4}$ Teuku Umar University, Indonesia, afwahayuningtyas@utu.ac.id \\ Coresponding author : Ramadhaniah, e-mail : ramadhaniah@gmail.com
}

\section{ABSTRACT}

To improve the nutritional quality of individuals and communities by improving consumption patterns, it could be obtained by achieving household nutrition indicators in Kecamatan Mila Kabupaten Pidie. The intensity of households consuming iodized salt has decreased by year in $2017(51 \%), 2018(44 \%)$, and $2019(31 \%)$. This condition resulted in 10 people having disorders due to iodine deficiency, 9 suffering goitre and one person suffering thyroid disease. The purpose of this study was to determine the factors associated with the use of iodized salt by housewives in Kecamatan Mila, Kabupaten Pidie, in 2020. This study used a cross-sectional analysis method. The result showed that based on univariate analysis, family knowledge and support were the most related variables with the use of iodized salt. In contrast, the health education variable (1.00) has no significant relationship with the use of iodized salt $(\mathrm{p}$-value $=0.00)$.
\end{abstract}

\section{ARTICLE INFORMATION}

\author{
Submitted: $22 / 10 / 2021$ \\ Revised: 28/10/2021 \\ Accepted: 29/10/2021 \\ Publish Online: 06/11/2021
}

\author{
Keywords: \\ Education \\ Family Support \\ Health Education \\ Knowledge \\ The Use of Iodized Salt
}

\section{How to cite this article: Ramadhaniah, Juwita, Amin, F. A., Hayuningtyas, A. (2021). Factors Associated to The Use of} Iodized Salt by Housewives in Kecamatan Mila Kabupaten Pidie in 2020. Journal of Nutrition Science, 2 (2), 5-11

\section{Introduction}

Efforts to improve community nutrition, as stated in UUD 1945 No. 362009 on health, aims to improve the nutritional quality of individuals and communities through improving food consumption patterns, improving nutrition-conscious behaviour, increasing access and quality of nutrition and health services by advances in science and technology (Kemenkes, 2018).

One of the Ministry of Health's strategy targets is all nutritionally aware families (KADARZI), as stated in the Decree of the Minister of Health No. 564/MENKES/SK/VIII/2006 regarding the guidelines for implementing "Desa Siaga" development. KADARZI is a family that can recognize, prevent, and overcome the nutritional problems of family members. A family is called KADARZI if it has good nutritional behavior continuously. The nutritional awareness behaviors expected to be realized at a minimum are: regularly weighing, giving breast milk (exclusive breastfeeding), eating a variety of foods, using iodized salt, and taking nutritional supplements as recommended (Notoatmodjo, 2012).

Efforts to improve nutrition status involve promoting a balanced diet, including nutrition counseling at the healthcare center, food fortification, providing additional food including complementary feeding, and providing nutritional supplements (vitamin A capsules and blood-supplementing tablets/TTD), monitoring and prevention of malnutrition. There are still many families who have not behaved well in nutrition, so that the reduction in nutritional problems is slow (Kemenkes, 2018).

The highest incidence of iodine deficiency disorder (IDD) in the world is in the European region, as much as $52.0 \%$, while Southeast Asia is in fourth place, which is $30.0 \%$ after the East Mediterranean, which is $47.2 \%$ and Africa, which is $41.5 \%$ (WHO, 2007). The prevalence of goiter in elementary school children in 2005 in Indonesia had a TGR (Total Goiter Rate) of $44.9 \%$. Monitoring data for iodized salt in Indonesia from 2006 to 2010 showed that 
$71.5 \%$ of iodized salt samples met the requirements (MS) (Kemenkes, 2013).

One of the IDD prevention programs is the fortification of iodine in salt. Universal Salt Iodization (iodized salt for all) is a long-term program to eliminate IDD problems. The problem of IDD is estimated to be eliminated if more than $90 \%$ of households have consumed salt-containing sufficient iodine. Based on data on the achievement of nutrition indicators in households in the working area of the Health Service of Kabupaten Pidie from 26 sub-districts of household orders that consume iodized salt in January to December 2017 about 25\%, in January-December 2018 23.7\% and JanuaryAugust 2019 20\% (Depkes RI, 2008)

Based on the profile data of Mila Health Center, the population in the area is 10285 people with the number of family cards as many as 2793 families. Based on nutrition achievement data on iodized salt, the achievement was $51 \%$ in $2017,44 \%$ in 2018 , and $31 \%$ use of iodized salt in the Mila Health Center area. From this data, it can be seen that there is a decrease in the use of iodized salt every year. This condition causes 10 people to experience disorders due to iodine deficiency (IDA), 9 of them suffering goiter and one suffering thyroid disease (Depkes RI, 2007).

Various factors can be the cause of the desire of housewives to use iodized salt. Characteristics of a person can affect every human being, including age, gender, education level, and the marital status during work in the organization (Ribhan, 2008). The other factors that may cause the low usage of iodized salt are there are many non-iodized salts that available in the market with the lower price compared to the price of iodized salt and the low of community's knowledge about the benefits of iodized salt, which will then affect their attitude in using iodized salt (Bag, Gizi Puskesmas Ponre, 2016).

This study aims to determine the factors related to the use of iodized salt in housewives in Kecamatan Mila, Kabupaten Pidie.

\section{Method}

This research is analytic with a cross-sectional design, which means that the research is designed to study the research variables by using an approach or collecting data at the same time (point time approach). The population in this study were all housewives in the Kecamatan Mila Work Area, Kabupaten Pidie, in 2020, which amounted to 2841 housewives. The Cluster Random Sampling Technique carried out the sampling method with the determination of inclusion and exclusion criteria. The data were obtained from interviews and headman in Kecamatan Mila, Kabupaten Pidie. The instrument in this study used a questionnaire.

The dependent variable in this study is the use of iodized salt, while the independent variables include knowledge, education, family support, and health education. Univariate analysis was conducted to describe each research variable using the mean value. Bivariate analysis was carried out to see between the dependent variable and the independent variable.

\section{Results}

Table 1. The frequencies distribution of factors associated to the use of iodized salt by housewives in Kecamatan Mila Kabupaten Pidie in 2020

\begin{tabular}{lcc}
\hline \multicolumn{1}{c}{ Variable } & Total Respondent \\
& N & \% \\
\hline Variabel Dependent & & \\
\hline Utilization of Iodized Salt & & \\
Using & 29 & 29.9 \\
Not Using & 68 & 70,1 \\
\hline Variabel Independent & & \\
\hline Knowledge & & \\
Good & 13 & 13,4 \\
Not Enough & 84 & 86,6 \\
Educational Background & & \\
High & 41 & 42,3 \\
Middle & 43 & 44,3 \\
Low & 13 & 13,4 \\
Family Support & & \\
Good & 64 & 66 \\
Not Enough & 33 & 34 \\
Health Education & & \\
Received & 95 & 97,9 \\
Not received & 2 & 2,1 \\
\hline
\end{tabular}

Table 1. shows that the majority of utilization of iodized salt is in not using category $(70.1 \%)$, the knowledge majority is not enough $(86.6 \%)$, the educational background majority in the middle $(43.3 \%)$, the family support majority in support $(66 \%)$, and health education majority in received $(97.9 \%)$. 
Table 2. Bivariate analysis of factors associated with iodized salt use by housewives in Kecamatan Mila Kabupaten Pidie in 2020.

\begin{tabular}{|c|c|c|c|c|c|}
\hline \multirow{3}{*}{$\begin{array}{c}\text { Independent } \\
\text { Variable }\end{array}$} & \multicolumn{5}{|c|}{ Utilization of Iodized Salt } \\
\hline & \multicolumn{2}{|r|}{ Yes } & \multicolumn{2}{|r|}{ No } & \multirow[t]{2}{*}{$\overline{P \text { P-value }}$} \\
\hline & $\mathbf{N}$ & $\%$ & $\mathbf{N}$ & $\%$ & \\
\hline \multicolumn{6}{|l|}{ Knowledge } \\
\hline Good & 12 & 92,3 & 1 & 7,7 & \multirow[b]{2}{*}{0,000} \\
\hline Not Enough & 17 & 20,2 & 67 & 79,8 & \\
\hline \multicolumn{6}{|c|}{ Educational Background } \\
\hline High & 19 & 65,5 & 22 & 32,4 & \multirow{2}{*}{0,023} \\
\hline Middle & 8 & 27,6 & 35 & 51,5 & \\
\hline Low & 8 & 60,9 & $\Phi 1$ & 86,5628 & 56625 \\
\hline \multicolumn{6}{|c|}{ Family Support } \\
\hline Yes & 27 & 93,1 & 37 & 54,4 & \multirow{2}{*}{0,000} \\
\hline No & 2 & 6,9 & 31 & 45,6 & \\
\hline \multicolumn{6}{|c|}{ Health Education } \\
\hline Received & 29 & 100 & 66 & 97,1 & \multirow{2}{*}{1,000} \\
\hline Not received & 0 & 0 & 2 & 2,9 & \\
\hline
\end{tabular}

Based on Table 2. above, there are three variables related ( $\mathrm{p}$-value $<0.05$ ) to the use of iodized salt, and there is one variable (health education (p-value 0.05 ) that has no relationship with the use of iodized salt.

\section{Discussion \\ Relationship between Knowledge and The Use of Iodized Salt}

The results of this study indicate that there is a significant relationship between knowledge and the use of iodized salt in Kecamatan Mila, Kabupaten Pidie in 2020, the p-value of $0.00<0.05$ was obtained. The result is in line with previous research by Wardani (2015) conducted in Purworejo Regency in 2011, which showed there was a significant relationship between knowledge and mother's behavior in using iodized salt. Another research by Yuni (2017) reported that many factors can affect housewives who have low knowledge but still consume iodized salt, including they are accustomed to using iodized salt (refined salt).

Knowledge about health has a very important role in determining someone's personal health. The broad knowledge and understanding of health correlate with their awareness of health (Eko Suryani and Hesty Widyasih, 2008:40). However, knowledge is not enough to make a person accept health values. Acceptance of health values is influenced by someone's belief in health. Belief in the good or bad value of health is based on its assessment of the perceived benefits and in terms of emotional/psychological, social, economic, perceived losses and consequences, as well as perceived obstacles (Eko Suryani and Hesty Widyasih, 2008).

\section{Relationship between Educational Background and The Use of Iodized Salt}

Education is an activity or human effort to improve personality by fostering personal potential in the form of spiritual (creation, taste, and intention) and physical (five senses and skills). Education is the result of achievements achieved by human development and the efforts of these institutions in

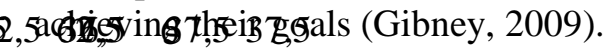

Education can be done formally or informally to provide understanding and change behavior (Meliansari, 2013). Women play a very important role in education at home. They instill habits and become role models for future generations regarding the treatment of the environment. To be able to carry out this education well, women need to be educated both formally and non-formally because a mother can take care of and educate her child well if she is educated (Gusti Ayu, 2013).

From the results of the study, it is known that the educational background has a relationship with the use of iodized salt, where the p-value is $0.023<0.05$. The higher the education level of the head of the household, the more households that use iodized salt. This is reinforced by the results of the chi-square statistical analysis, which shows a significant relationship between the education level of the head of the household and the use of iodized salt $(\mathrm{p}=$ 0.000). Likewise, the wife's education level shows that the higher the wife's education level, the more use of iodized salt. The statistical analysis results showed a significant relationship between the housewife educational background and the use of iodized salt $(\mathrm{p}=0.000)$.

The higher the level of education, the greater their awareness of using iodized salt. This is in line with several previous findings. The higher the education level of the head of the family, the greater the percentage of families using iodized salt. Mother's education level is the dominant factor related to the use of iodized salt in households in Mojogemi Village, Sukowono Jember through the results of his research in Ulak Karang Selatan Village, Padang reported that the use of iodized salt in households is related to family education level (Muliasari D, 2011). 


\section{Relationship between Family Support and The Use of Iodized Salt}

This study indicates that family support has a significant relationship with the use of iodized salt, and the p-value is 0.000 . The results of the study on support (family/neighborhood/health workers/ village leaders) with the use of iodized salt at the household level showed that mothers who did not receive support with the use of iodized salt at the household level did not have enough iodine as many as 42 respondents $(71.2 \%)$ and 17 respondents $(28.8 \%)$. Meanwhile, 6 respondents $(28.6 \%)$ did not receive support using iodized salt at the household level, and 15 respondents $(71.4 \%)$. Based on table 1 , the results of statistical analysis state that there is a significant relationship between support (family/neighbors/ health workers/village leaders) and the use of iodized salt at the household level (Sutiah, 2017).

Family support is defined as verbal or non-verbal information, advice, tangible assistance, or behavior provided by people who are familiar with the subject in their environment or in the form of presence and things that can provide emotional benefits and affect the behavior of the recipient. In this case, people who feel emotionally supported feel relieved because they are cared for and get suggestions or a pleasant impression (Smet, 1994 in Christine, 2010).

Family support is a process that occurs throughout life. The nature and type of support differ in different stages of the life cycle. Family support can be in the form of internal social support, such as support from husband, wife, or support from siblings, and can also be in the form of external family support for the family. Family support makes the family able to function with various intelligence and senses. As a result, it improves family health and adaptation (Friedman., M. 2010).

\section{Relationship between Health Education and The Use of Iodized Salt}

The amount of services provided by health workers by providing health education is $97.9 \%$. Based on Table 2. it is known that mothers who use iodized salt based on counseling are $100 \%$, and those who do not use iodized salt but extension officers provide counseling are $97.1 \%$ compared to mothers who do not receive counseling and do not use iodized salt only $2.9 \%$. Based on the results of the p-value obtained $1,00<0.05$, the conclusion is that there is no significant relationship between health education and the use of iodized salt in Kecamatan Mila, Kabupaten Pidie in 2020. This means that the health education provided by health workers from the Mila Health Center does not change the community.

According to Suliha et al. (2012), health education is a process of change in a person associated with achieving individual health goals and society. Health education cannot be given to someone by another person, not a set of procedures that must be carried out or a product that must be achieved, but is a dynamically changing developmental process, in which a person accepts or rejects new information, attitudes, and practices related to the goal of healthy living.

The influence of customs in receiving new information cannot be ignored because our society still values and considers something that should not be ignored. In public trust, people pay more attention to information conveyed by people they already know because public trust has arisen with conveying information. When delivering information, the availability of time in the community must pay attention to the level of community activity to ensure the level of community presence in counseling.

The results of the research on health worker counseling showed that the results of the analysis showed a relationship between health worker counseling and the use of iodized salt at the household level. Providing health education about iodized salt, in general, will increase a person's knowledge so that the person will have good behavior in choosing and using iodized salt in daily life.

\section{Conclusion}

Conclusion: There is a significant relationship between mother's knowledge, mother's last education, family support, and the use of iodized salt in Kecamatan Mila, Kabupaten Pidie in 2020. However, there is no significant relationship between health education and the use of iodized salt. Knowledge and family support are the most dominant factors related to the use of iodized salt in Kecamatan Mila, Kabupaten Pidie in 2020.

Recommendation: (i) The health office and related agencies should be able to guarantee the availability of iodized salt in the field by monitoring the distribution of iodized salt in the market and monitoring iodized salt in the community, as well as involving the community in ensuring the availability of iodized salt within the scope of housewives by storing iodized salt and processing salt at home. cooking process properly so that the consumption of iodized salt can increase. (ii) it is hoped that housewives will be able to increase efforts to 
improve the family's nutritional status, especially in terms of using iodized salt in the right way, as well as reducing the consumption of goitrogenic substances. (iii) The need for the husband's support and participation in using iodized salt by providing information on the use of iodized salt, both from the benefits and impacts of iodine deficiency. (iv) It is necessary to improve monitoring, counseling, and promotion of iodized salt on a regular basis in order to achieve the status of "families with good consumption of iodized salt" by using leafleat, audiovisual and social media. In addition, there is guidance for producers to provide adequate iodine according to the Indonesian National Standard (SNI), containing as much as $30-80 \mathrm{ppm}$ in collaboration with surrounding sectors.

\section{References}

Agus, I. (2006). Basic Concept Statistics and Its Applications. Jakarta: Kencana Prenada Media.

Agus, I. (2014). Introduction to Food and Nutrition. Jakarta: Penebar Swadaya.

Agustin, H., Budiman, H., \& Faiza, Y. (2015). Factors Associated with the Incidence of Disorders Due to Iodine Deficiency in Koto Tangah District. Jurnal Kesehatan Komunitas, 2 (6): 262-269

Almatsier, S. (2004). Basic Principles of Nutrition. Jakarta: Gramedia Pustaka Umum.

Amalia, L., et al. (2015). Knowledge, Attitudes, and Practices of Maternal Nutrition Related to Iodine and Selection of Types of Household Salt in the Cianjur Mountains Region. Jurnal Gizi Pangan, 133-140.

Arisman. 2004. Nutrition in the Life Cycle. Jakarta: EGC.

Astuti, W. (2016). Analysis of the relationship between knowledge, attitudes, and nutritional practices of housewives with the use of iodized salt in the district of Bogor. Skripsi

Devi, M. (2012). The Relationship of Iodized Salt Use with Children's Linear Growth. Jurnal TIBBS (Teknologi Industri Boga dan Busana), 3 (1): $52-57$

Depkes RI, 2003, Pedoman Umum Gizi Seimbang (Panduan untuk Petugas), Jakarta: Bakti Husada.

2004, Peningkatan Konsumsi Garam Beryodium, Jakarta: Tim Penanggulangan GAKY Pusat.

2005, Rencana Aksi Nasional Kesinambungan Program Penanggualangan
Gangguan Akibat Kekurangan Yodium, Jakarta: Tim Penanggulangan GAKY Pusat.

2007, Pedoman Pemantauan Wilayah Setempat (PWS) Konsumsi Garam Beryodium untuk Semua (KGBS) di Rumah Tangga, Jakarta: Tim Koordinasi Penanggulangan GAKY.

, 2008, Laporan Hasil Riset Kesehatan Dasar Jawa Tengah tahun 2007, Jakarta: CV. Metro Nusa Prima.

Eko Suryani dan Hesty Widyasih, 2008, Psikologi Ibu dan Anak, Yogyakarta: Fitramaya.

Erlangga, Yoga Pratama. 2014. Hubungan Frekuensi Konsumsi Bahan Makanan Sumber Yodium Dengan Fungsi Kognitif Anak Dan Prestasi Belajar Anak Sekolah Dasar Penderita Gaky Di Sd Negeri Ngargoyoso 2 Kabupaten Karanganyar. Skripsi : Gizi Fakultas Ilmu Kesehatan Universitas Muhammadiyah Surakarta.

Gusti Ayu M.P dan NI Komang E. 2013. Gambaran Pengetahuan, Sikap dan Perilaku Ibu Rumah Tangga terhadap Garam Beryodium di Desa Lodtuduh Wilayah Kerja UPT Kesehatan Masyarakat Ubud, Community Healt, Volume 1, No.2 juli 2013.

Gibney, Michael J, et al. 2009. Public Health Nutrition. Diterjemahkan oleh dr. Andry Hartono dengan judul Gizi Kesehatan Masyarakat. Jakarta: EGC.

Handayani, E., Saraswati, D. D., \& Munayarokh. 2013. Perbedaan Tingkat Pengetahuan dan Sikap Ibu Hamil tentang Penggunaan Garam Beriodium di Wilayah Puskesmas Borobudur Kabupaten Magelang Tahun 2013. Jurnal Kebidanan, 2 (5): 20-27.

Handoko Riwidikdo, 2007, Statistik Kesehatan, Yogyakarta: Mitra Cendikia Press.

Hikmawati, Andi. 2012. Faktor-faktor yang berhubungan dengan konsumsi garam beryodium di rumah tangga di Dusun Kasimburang Desa Belapunranga Kecamatan Parangloe Kabupaten Gowa. Skripsi; Fakultas ilmu kesehatan UIN Alaauddin Makassar.

Kurniasari, Atika. 2012. Hubungan antara pengetahuan dan sikap tentang GAKY dengan kadar yodium garam konsumsi pada keluarga petani garam. Semarang : Skripsi Ilmu Gizi Fakultas Kedokteran Universitas Diponegoro.

Kemenkes RI. 2013. Riset Kesehatan Dasar; RISKESDAS. Jakarta: Balitbang Kemenkes RI. 
Kemenkes RI. 2018. Laporan hasil riset kesehatan dasar (riskesdas) Indonesia tahun 2007. Jakarta: Kementerian Kesehatan Republik Indonesia;

Mandias R., Hubungan Tingka pendidikan dengan Perilaku Masyarakat desa dalam Memanfaatkan Fasilitas Kesehatan di Desa Pulisan Kecamatan Likupang Timur, Minahasa Utara. JKU, Vol.1, Juni 2012.

Meliansari. 2013. Gambaran Garam Beryodium Pada Berbagai Merek Garam Di Pasar Ciputat. Jakarta : Skripsi Fakultas Kedokteran Dan Ilmu Kesehatan UIN Syarif Hidayatullah.

Muhibbin, Syah. 2010. Psikologi Pendidikan Dengan Pendekatan Baru. PT Remaja Rosdakarya. Bandung.

Martomijoyo, Riyanto. 2016. faktor-faktor yang berhubungan dengan penggunaan garam beryodium pada rumah tangga desa Jatibarang baru Kabupaten Indramayu.

Mustamin dkk. 2015. Gambaran Pengetahuan Dan Praktek Penggunaan Garam Beriodium Di Lingkungan Belang-Belang Kelurahan Maccini Baji Kabupaten Maros.

Nadimin. 2016. Hubungan Tingkat Pendidikan dengan Penggunaan Garam Beriodium Tingkat Rumah Tangga di Sulawesi Selatan. Media Kesehatan Masyarakat Indonesia (MKMI), 11 (4): 1-63

Nisfulaeli A. Ramlan D, Budiyanto S., Beberapa Faktor yang Berhubungan dengan Penggunaan Garam Beriodium Ibu Rumah Tangga di Desa Kecepak Kecamatam Batang kabupaten Batang. Fakultas Kesehatan Masyarakat, Universitas Jendral Soedirman, 2015.

Notoatmodjo, Soekidjo. 2012.Promosi Kesehatan dan Perilaku Kesehatan. Jakarta: Rineka Cipta.

Novitasari, Siti. 2014. Hubungan Antara Tingkat Pengetahuan Dan Sikap Ibu Rumah Tangga Dengan Penggunaan Garam Beryodium Di Desa Selo Kecamatan Selo Kabupaten Boyolali. Surakatra : Skripsi Fakultas Ilmu Kesehatan Universitas Muhammadiyah.

Pandav CS; Jooste PL; West CE. 2004. Gizi Kesehatan Masyarakat. Jakarta : EGC.

Permatasari, Inke indah. 2013. Hubungan Pengetahuan, Sikap dan Praktik Gizi Ibu dengan Konsumsi Pangan Sumber Yodium dan Penggunaan Jenis Garam Rumah Tangga di Wilayah Pegunungan Kabupaten Cianjur. Skripsi; Fakultas Ekologi manusia IPB.
Prawini, G. A. M., \& Ekawati, N. K. 2013. Gambaran Pengetahuan, Sikap Dan Perilaku Ibu Rumah Tangga Terhadap Garam Beryodium Di Desa Lodtunduh Wilayah Kerja UPT Kesehatan Masyarakat Ubud I Tahun 2013.

Riset Kesehatan Dasar. 2012. Laporan Nasional . Departemen Kesehatan Republik Indonesia.2013. Laporan Nasional. Jakarta. Departemen Kesehatan Repoblik Indonesia.

Sanjaya, Wina. 2011. Strategi Pembelajaran Berorientasi Standar Proses Pendidikan. Jakarta:Kencana Prenada Media.

Sastroasmoro, Sudigdo. 2011. Dasar-dasar Metodologi Penelitian Klinis Edisi Ke-4. Jakartan : Sagung Seto.

Setyani, Asih.,dkk. 2011. Hubungan faktor perbedaan individual dan ketersediaan garam di warung dengan perilaku ibu rumah tangga dalam penggunaan garam beryodium di Kabupaten Purworejo. MGMI Vol. 1, No. 4, Juni 2011: 135-142.

Shihab, M. Quraisy. 2012. Tafsir Al- Misbah: Pesan, kesan dan keserasian Al-Quran Volume 12. Jakarta: Lentera Hati. (2012). Tafsir AlMisbah: Pesan, kesan dan keserasian Al-Quran Volume 14. Jakarta: Lentera Hati.

Sutiah, Galuh N.P., dan Oktia Woro KH, Faktor Yang Berhubungan Dengan Penggunaan Garam Beryodium Tingkat Rumah Tangga, Jurnal Of Health Education, JHE 2 (2) (2017).

Sukirno S. 2008. Mikro ekonomi teori pengantar. Jakarta: PT Raja Grafindo Persada.

Syarfaini. 2012. Dasar-Dasar Ilmu Gizi. Makasar : Alauddin Pres.

Sulistyawati. 2014. Deteksi Tumbuh Kemabang Anak. Jakarta: Salemba Medika pp.

Susilaningrum et al., 2013. Asuhan Keperawatan Bayi dan Anak untuk Perawat dan Bidan. Jakarta : Salemba Medika pp. 35-37, 43-44.

Tyas. 2013. Hubungan antara Pemberian ASI Eksklusif dan ASI Non Eksklusif dengan Pertumbuhan Berat Badan Bayi 0-6 Bulan di Desa Giripurwo Wonogiri. Skripsi. Utaminingrum \& Sartono. 2012. Hubungan Pengetahuan Ibu, Pendidikan Ibu dan Dukungan Keluarga dengan Praktek Pemberian ASI Eksklusif di Kelurahan Muktiharjo Kidul Kecamatan Telogosari Kota Semarang. Jurnal Gizi Universitas MuhammadiyahSemarang. 1: 1-9. 
TA, Moch Imron. 2010. Metodologi Penelitian Bidang Kesehatan.Jakarta

Tjiptoherijanto P, Soesetyo B. 2008. Ekonomi kesehatan. Jakarta: Rineka Cipta

Wardani, Setyawati Ika. 2015. Hubungan Pengetahuan Dan Pengelolaan Garam Dengan Ekskresi Yodium Urin Ibu Hamil Di Puskesmas Musuk 1 Kecamatan Musuk Kabupaten Boyolali. Surakarta : Skripsi
Fakultas Ilmu Kesehatan Universitas Muhammadiyah.

Yuni Astutik, Vivin. 2017. Tingkat Pengetahuan, Pola Kebiasaan Lingkungan Hidup Berhubungan Dengan Motivasi Ibu Dalam Memilih Kondisi Garam. Jurnal Care Vol .5, No 2,Tahun 2017 